\title{
Use of non-wood biomass combustion ash in development of alkali-activated
}

\section{concrete}

\author{
${ }^{1}$ Ph.D. Student, Dept. of Civil and Environmental Engineering, Michigan State University, 1542 Linden \\ Street, East Lansing, 48823. E-mail: Matalkah@msu.edu \\ ${ }^{2}$ Professor, Dept. of Civil and Environmental Engineering, Michigan State University, 3546 Engineering \\ Building, E. Lansing, MI, USA 48824-1226. E-mail: Soroushi@egr.msu.edu \\ ${ }^{3}$ Chemist, Metna Co., 1926 Turner St., Lansing, MI, USA 48906. E-mail: $\underline{\text { Sametnaco@ gmail.com }}$ \\ ${ }^{4}$ Project Manager, Stantec Consulting Services Inc., 500 Main St., Baton Rouge, LA, USA, 70801. Email: \\ Amirpasha.peyvandi@gmail.com
}

Abstract: The work reported herein focuses on demonstrating the value of non-wood biomass combustion ash in production of alkali-activated concrete. The growing use of biomass as fuel leaves significant quantities of solid residue (ash) with qualities that are different from those of coal combustion ash. The composition of biomass ash suits development of alternative cement chemistries with significantly reduced carbon footprint and energy content when compared with Portland cement. Sustainable cement chemistries relying upon alkali aluminosilicate hydrate as the primary binder are receiving growing attention. Combustion ashes of wheat straw, switch grass, corn cob, alfalfa stem, corn stalk, cotton gin and rice hull were evaluated in this investigation. Characterization of the chemical composition, mineralogy, degree of crystallinity, solubility, $\mathrm{pH}$ in solution, loss on ignition, morphology and particle size distribution of non-wood biomass ashes, and the strength and moisture stability of the resulting concrete provided a basis for assessment of the merits of non-wood biomass ash as reactive raw materials in production of alkali-activated concrete.

Key words: non-wood biomass combustion ash; alkali aluminosilicate hydrate; cementitious binder; concrete; sustainability 


\section{Introduction}

2 Non-wood biofuels (e.g., agricultural wastes) are among alternative fuels that are carbon neutral.

3 Extraction of value from biomass in biorefineries is a growing practice [1]. Combustion ashes are the by-

4 products of biomass combustion in power plants and biorefineries [1]. The relatively high silica and alkali

5 contents of non-wood biomass ash are of value towards production of alkali aluminosilicate hydrate-

6 based binders for high-performance and sustainable concrete materials. Table 1 compares examples of ash

7 contents and compositions in combustion of wood, wheat straw, and algae. Combustion ashes of wheat

8 straw and algae (examples of non-wood biomass) are distinguished from wood combustion ash by

9 significantly reduced $\mathrm{CaO}$ contents, substantially increased $\mathrm{SiO}_{2}$ and alkali $\left(\mathrm{Na}_{2} \mathrm{O}+\mathrm{K}_{2} \mathrm{O}\right)$ contents, greater

$10 \mathrm{Cl}$ contents (washing can lower the $\mathrm{Cl}$ content of ash[2]), and reduced heavy metal concentrations.

$<$ Table 1>

14 Coal fly ash is now used in massive quantities as a partial replacement for cement in concrete [3]. Major research investigations have thus focused on the potential value of biomass combustion ash as a supplementary cementitious material in conventional concrete [4-7]. While some promising results have

17 been produced with wood combustion fly ash as replacement for $\sim 10 \mathrm{wt} . \%$ of cement, the relatively high

18 alkali content of wood waste ash is a drawback for the concrete industry which is highly concerned with

19 deleterious alkali-silica reactions. In the case of wood waste ash with moderately high alkali content, the

20 relatively low $\mathrm{C} / \mathrm{S}$ ratio of the $\mathrm{C}-\mathrm{S}-\mathrm{H}$ generated by the pozzolanic reaction of the biomass ash enables

21 binding of relatively high quantities of alkalis within the C-S-H structure [5]. This phenomenon controls

22 the potential for deleterious alkali-silica reactions in concrete incorporating wood combustion ash as

23 partial replacement for cement [5]. The high alkali contents of non-wood combustion ashes, however,

24 seriously challenge the potential for their use as supplementary cementitious materials in concrete. An

25 alternative approach for value-added use of non-wood biomass combustion ash, pursued in this study, 
takes advantage of the high alkali content of biomass ash towards producing structural grade binders

2 based on alkali aluminosilicate hydrates. This activation process involves reactions between non-wood

3 biomass ash, which can be classified (either inherently or after augmentation) as an aluminosilicate $\left(\mathrm{AS}_{\mathrm{y}}\right)$,

4 and an alkali silicate solution $\left[\mathrm{RS}_{\mathrm{z}}\right.$ (aq.)] (typically blended with alkali hydroxide) in water (H): $A S_{y}+$

$5 R S_{z}$ (eq.) $+n H \rightarrow R A S_{(y+z)} H_{n}$. This is a polycondensation reaction in which the dissolved alkali silicate

6 cross-links with the reactive aluminosilicate to form high-performance solid structures with significant

7 binding attributes.[3] The alkalis in biomass ash feasibly take part in this reaction. The resulting hydrates

8 incorporate relatively low chemically bound water contents when compared with the hydration products

9 of Portland cement.

10 Binders based on alkali aluminosilicate hydrates offer the potential to yield lower carbon footprint and

11 energy content when compared with Portland cement [8-10]. Unlike the 1D structure of calcium silicate

12 hydrate, the primary binder among ordinary cement hydrates, which relies upon weak secondary bonds to

13 form a 3D structure, alkali-activated aluminosilicates form an extended 3D structure with primary bonds

14 via polycondensation $[11,12]$.

15 Alkali-activated aluminosilicate binders are formed by through-solution chemical reactions between the

16 dissolved constituents of various aluminosilicate precursors with alkaline earth and alkali metal cations

17 that are present in an alkaline solution [13]. These reactions yield predominantly alkali and calcium

18 aluminosilicate hydrates [14], and tend to occur at higher rates than hydration of ordinary Portland

19 cement. The extended 2D/3D structure of calcium/alkali aluminosilicate hydrates, and their relatively low

20 content of chemically bound water, distinct molecular-scale porous morphology and robust chemistry

21 explain their advantages over the hydration products of ordinary Portland cement (primarily calcium

22 silicate hydrate). Some key performance advantages of alkali-activated aluminosilicates are: (i) stability

23 under weathering and chemical attack; (ii) impermeability; (iii) encapsulation of hazardous materials; (iv)

24 fire resistance; (v) abrasion/erosion resistance; (vi) dimensional stability; (vii) rate of strength gain and

25 ultimate strength; and (viii) adhesion and binding qualities [15-19]. The potential for reducing carbon 
1 footprint and energy content are also among the advantages of alkali-activated aluminosilicate binders

2 versus ordinary Portland cement hydrates [8, 9]. Continued hydration of ordinary Portland cement

3 requires input of moisture to retain close to $100 \%$ relative humidity, which challenges practical

4 achievement of advanced hydration states in field conditions. The alkali-activated aluminosilicate binder

5 structure, on the other hand, continues to develop in ambient condition without the need for external input

6 of moisture; this is because water is consumed and then regenerated in alkali-activation of

7 aluminosilicates [11].

8 The work reported herein has developed alkali-activated aluminosilicate binders for concrete production

9 which by making value-added use of the combustion ashes of non-wood biomass which are rich in silica,

10 alkalis, and (to a lesser extent) alumina. Non-wood biomass ash is formulated with supplementary

11 materials in order to achieve a desired chemical balance and particle size distribution for production of

12 high-performance, low-cost, sustainable and environmentally safe alkali-activated biomass ash-based

13 concrete.

\section{Value of non-wood biomass ash in production of alkali-activated aluminosilicate binders}

16 Alkali-activated materials encompass binder systems derived by reaction of an alkaline salt with a solid

17 silicate powder. The alkaline salts used in the process are essentially any soluble substance which can

18 raise the $\mathrm{pH}$ of the reaction mixture and accelerate dissolution of the solid precursor. When compared

19 with ordinary Portland cement, alkali-activated binders have a high degree of silicate connectivity, and a

20 higher ratio of $\left(\mathrm{SiO}_{2}+\mathrm{Al}_{2} \mathrm{O}_{3}\right)$ to $\left(\mathrm{CaO}+\mathrm{Na}_{2} \mathrm{O}\right)$. While alkali-activated binders tend to have lower calcium

21 contents that Portland cement binders, the presence of calcium is important to the stability and long-term

22 performance of alkali-activated binders [20, 21]. These binders assume a high degree of moisture

23 resistance and chemical stability as far as they can produce a highly coordinated (overwhelmingly $\mathrm{Q}^{4}$ )

24 'geopolymeric' structure. Alkali-activated materials with relatively high aluminum contents can assume 
this 'geopolymeric' structure. Figure 1 shows the calcium and aluminum contents of geopolymer versus those of other binders including alkali activated materials and Portland cements.

$<$ Figure 1>

While aluminosilicate-based binders offer distinct qualities for solidification/stabilization of heavy metals, the concentration of heavy metals would still be a consideration in selection of biomass ashes as aluminosilicate precursors. Another important issue is the effect of the contaminants present in biomass ash, that could add reaction pathways which affect the fresh mix rheology, set time, shrinkage, strength and other engineering properties of aluminosilicate-based binders [15]. Abundance, environmental impact and alternative applications are also important considerations in selection of non-wood biomass ashes for use as aluminosilicate precursors. The non-wood biomass type as well the combustion conditions determine the properties of the combustion ash. The residues formed during biomass combustion can be divided into bottom and fly ashes. The fly ash fraction typically consists of coarse and fine types. The coarse fly ash particles (larger than few $\mu \mathrm{m}$ ) form simply by entrainment of ash from the fuel bed. Formation pathways of the fine fly ash (aerosols with $<1 \mu \mathrm{m}$ particle size) involve release of volatile ashforming compounds $(\mathrm{K}, \mathrm{Na}, \mathrm{S}, \mathrm{Cl})$ and easily volatile heavy metals $(\mathrm{Zn}$ and $\mathrm{Cd}$, etc.) from the fuel into the gas phase, and their subsequent gas phase reactions and particle formation via nucleation or condensation of vapors on existing surfaces. Nucleation and condensation are competing processes; nucleation can be partly or even totally suppressed if there are adequate surfaces available for condensation. Otherwise, very small (few $\mathrm{nm}$ ) aerosol particles form. Upon formation, these particles start to coagulate with other aerosols and with coarser fly ashes [22].

This investigation will consider various types of ash resulting from combustion of abundant non-wood biomasses. Typical compositions of combustion ashes of these biomasses (and coal) are given in Table 2 . The alumina, silica, alkali and calcium oxide contents of non-wood biomass combustion ashes are of particular interest in their evaluation as precursors for production of binders based on alkali/calcium aluminosilicate hydrates. The high silica content of non-wood biomass ashes stands out in Table 2 . 
$<$ Table 2>

3. Materials and methods

\subsection{Materials}

6 Seven non-wood biomasses were obtained from different sources. Wheat straw was obtained from a farm

7 in Okemos, Michigan. Two crops of wheat straw were evaluated in order to make a preliminary

8 assessment of the variations in the qualities of the resulting ashes. Mid-Michigan switch-grass and corn

9 stover were obtained from mid-Michigan farms. Alfalfa stem was obtained from a farm in Williamston,

10 Michigan. Ungrounded rice hull was obtained from Riceland Food, Stuttgartm, Arkansas. Cotton stalk

11 and cotton gin were obtained through the USDA Agricultural Research Service in Lubbock, Texas.

12 In order to produce a desired chemical balance for formation of alkali aluminosilicate hydrates with 13 desired binding qualities and moisture resistance, coal fly ash was used together with non-wood biomass 14 ash, targeting viable silica-to-alumina ratios. Wheat straw ash was used in the formulation primarily as a 15 source of silica and alkalis. The binder was synthesized by activating the blend of biomass ash and coal 16 fly ash with using an alkaline solution comprising sodium hydroxide and sodium silicate dissolved in 17 water. The coal fly ash used in this study was obtained from a local ready-mixed concrete plant in 18 Lansing, Michigan. Metakaolin was used together with non-wood biomass (wheat straw) ash in order to 19 produce a desired silica-to-alumina ratio. The metakaolin used in this study was dry Metamax® powder 20 supplied by BASF with mean particle size of $1.3 \mu \mathrm{m}$. Table 3 shows chemical compositions of the coal 21 fly ash and metakaolin used in this study. Silicon and aluminum oxides, which are critical to 22 geopolymerizaiton, constitute more than $96 \%$ of metakaolin; the silicon oxide-to-aluminum oxide weight 23 ratio of this metakaolin is close to 1 . In the case of coal fly ash, the silicon and aluminum oxides 24 constitute about $75 \%$ of the total mass, and the ratio of silicon oxide-to-aluminum oxide is about 2 . With 
1 a calcium oxide content of $14.3 \%$, this coal ash may be classified as ASTM C618 Class F, but it is at the

2 borderline of Class F and Class C coal fly ashes.

$\langle$ Table 3>

4

5 Limestone with ASTM C33 \#8 particle size distribution was used as coarse aggregate, and natural sand as

6 fine aggregate. The fineness modulus of combined aggregates was 5.0. The particle size distributions of 7 the coarse and fine aggregates are presented in Table 4.

\section{8}

11 The alkaline solution used was a combination of sodium silicate solution and sodium hydroxide solution.

12 The sodium silicate solution used in this study was acquired from PQ Corporation $\left(28.7\right.$ wt.\% $\mathrm{SiO}_{2}, 8.9$

13 wt.\% $\mathrm{Na}_{2} \mathrm{O}, 62.4$ wt.\% $\left.\mathrm{H}_{2} \mathrm{O}\right)$ with density of $1.39 \mathrm{~g} / \mathrm{cm}^{3}$ and $\mathrm{pH}$ of 11.30 . The sodium hydroxide $(\mathrm{NaOH})$

14 was purchased from Sigma Aldrich in pellet form with $97 \%-98 \%$ purity. The $\mathrm{NaOH}$ solid pellets were

15 dissolved in water to make the solutions of $6 \mathrm{M}, 10 \mathrm{M}, 14 \mathrm{M}$ and $18 \mathrm{M}$ concentrations. [23] In order to

16 improve the workability of fresh concrete, sodium tetraborate-based (borax) was added to the mixture at

17 low concentration.

\subsection{Methods}

20 A 20 Quart planetary mixer (Hobart A-200) was used to prepare concrete mixtures. The blended powders

21 were first mixed for about 1 minute at medium speed. The sodium hydroxide solution was then added to 22 the dry powder blend, and the mixing was continued for 30 seconds. The sodium silicate solution was 23 then added, and mixed for another 30 seconds. Fine and coarse aggregates were added subsequently, and

24 mixing was continued for about 3 minutes to produce a homogeneous mixture. The fresh concrete was 25 cast into molds immediately after mixing, and vibrated for 2 minutes at medium speed. The fresh mix 
workability was measured using the flow table test per ASTM C1473 procedures. The initial and final set

2 times were measure following ASTM C403 procedures. Compression tests were performed per ASTM

3 C109.

4 Laboratory-scale combustion of biomass was implemented with the objective of simulating large-volume

5 combustion of biomass in power plants. The first step in the process involved combustion of a small

6 volume of biomass in a burner with natural air flow. Biomass was ignited with flame, and allowed to burn

7 by itself with ample air supply at a temperature of about $350^{\circ} \mathrm{C}$. This combustion temperature is below

8 that used in industrial power plants, and the resulting ash has a relatively high LOI. In order to approach

9 the ash quality obtained in an industrial power plant, the ash obtained in the first step was subjected to

$10550^{\circ} \mathrm{C}$ for four hours in a box furnace (Model S1200C-161622 manufactured by Sentro Tech Corp.). The

11 resulting non-wood biomass combustion ash was milled in order to produce the micro-scale particle size

12 distribution which benefits hydration reactions. Non-wood biomass ashes were milled for four hours in a

135.6 liter ceramic jar, using steel balls with 5-10 mm diameter; the ash-to-steel ball mass ratio was 1: 10.

14 While industrial-scale combustion of biomass generates fly ash with desired particle size distribution for

15 direct use in hydration and geopolymerization reactions, the laboratory-scale combustion employed here

16 produced ash particles that benefited from size reduction via ball-milling.

17 Scanning electron microscope observations of non-wood biomass ash were performed using a JEOL

18 JSM-6610LV scanning electron microscope (JEOL Ltd., Tokyo, Japan). For the purpose of scanning

19 electron microscopy, the non-wood biomass ash specimens were coated with a 20 -nm thick platinum

20 layer in an Emscope Sputter Coater model Sc 500 (Ashford, Kent, England) purged with Argon gas.

21 The mineralogy of ash samples was assessed via x-ray diffraction (XRD) using a Bruker D8 daVinci

22 diffractometer equipped with $\mathrm{Cu}$ x-ray radiation operating at $40 \mathrm{kV}$ and $40 \mathrm{~mA}$. Peak intensities were

23 obtained by counting with the Lynxeye detector every $0.05^{\circ} 2 \theta / \mathrm{min}$. Powder XRD was carried out at a

24 reflection angle range of $2 \theta=10-80^{\circ}$. Qualitative analysis of the XRD patterns yielded the mineral

25 phases present in ash samples. The degree of crystallinity was determined using the EVA software. It is 
1 calculated as the ratio of the area under all peaks to the total area under the curve (i.e., the area under

2 peaks plus the area under the amorphous peak).

3 Dissolution experiments were conducted in order to make a preliminary assessment of how readily

4 aluminosilicates become available for the through-solution condensation reactions. For this purpose, $5 \mathrm{~g}$

5 of ash was dissolved in $100 \mathrm{ml}$ of $10 \mathrm{M} \mathrm{NaOH}$ solution, and the solution was stirred for different time

6 intervals. After stirring, the non-dissolved ash was filtered using $0.2 \mu \mathrm{m}$ filter paper [24].

7 Loss On Ignition (LOI) was measured for ashes obtained with nine different combustion conditions of

8 non-wood biomass in order to identify the preferred method of combustion. Following ASTM D7348, a

9 single-step procedure was used for measurement of LOI. Three specimens were tested for each

10 combustion condition, and the average value and $95 \%$ confidence interval were obtained.

11 The Particle size distribution of biomass ashes was evaluated using a laser particle size analyzer (Malvern

12 Mastersizer 2000E laser particle size analyzer). About 2 grams of ash was dispersed in a water-based

13 solution of sodium hexametaphosphate $\left(\left(\mathrm{NaPO}_{3}\right)_{13} \cdot \mathrm{Na}_{2} \mathrm{O}\right)$ within a glass vial by gently shaking the vial

14 for 2 hours.

15 The $\mathrm{pH}$ of ash in solutions was evaluated by adding ash to deionized water at $2 \%$ and $5 \%$ concentrations

16 by mass in a vial, and placing the solution on shaking table for 2 hours. A pH meter (Extech pH 110) was

17 used to determine the $\mathrm{pH}$ of the solutions.

18 Elemental analysis of ash was performed using the x-ray fluorescence (XRF) technique.

19 The mix design of wheat straw ash-based concrete is presented in Table 5. Concrete specimens were 20 molded, sealed, and retained at room temperature for 24 hours. This period allows for partial dissolution 21 of precursors prior to the curing step. The specimens were then demolded and subjected to 48 hours steam 22 curing at $80^{\circ} \mathrm{C}$ in order to advance and accelerate the hydration reactions. The specimens were then stored 23 at $50 \%$ relative humidity and room temperature in order to stabilize their moisture content prior to testing 24 at 7 days of age. 
1 Cubic specimens (50-mm dimensions) were used for compression tests following ASTM C109

2 procedures, and also for determining void content, water absorption capacity and density per ASTM

3 C642. This test involves immersion of specimens in water of equal weight for 48 hours [25].

4

5

6

7 The hydration process involves dissolution of aluminosilicate precursors and other chemical compounds

8 into the alkaline solution, and their reactions together with the alkali activator constituents to yield the

9 aluminosilicate-based binder. Solubility of the precursor constituents is thus an important consideration

10

11

12

13

14

15

$<$ Table 5>

which, besides the chemical composition of the precursor (e.g., wheat straw ash), influences the hydration process. This implies that theoretical balancing of the chemistry of precursors without accounting for their solubility may not be adequate in formulation of aluminosilicate-based binder systems. Therefore, an empirical optimization program was designed and implemented in order to devise an example optimum formulation of wheat straw ash-based binder. The optimization program considered three variables: solid activator-to-ash ratio, solid sodium silicate-to-sodium hydroxide ratio, and water-to-total solid ratio. Table 6 presents the three levels of these variables considered in the optimization experimental program, which produce viable chemical balances for hydration.[15, 26-28] The ratio of wheat straw ash-to-coal fly ash in this optimization program was kept constant at 1:1, with coal fly ash used primarily to supplement the low alumina content of wheat straw ash. The optimization experimental program was designed using the Box-Bhenken design procedure in the SYSTAT@ statistical software. 
3 The focus of the optimization experimental program was on maximizing the compressive strength of the

4 wheat straw ash-based concrete. In addition, the fresh mix flow, set time, and the hardened material void 5 content, water absorption capacity and density were determined.

\section{Experimental results: non-wood biomass ash characteristics}

7 Representative samples of the selected non-wood biomass combustion ashes were characterized in

8 laboratory. The physical and chemical characteristics of these ashes, which determine their potential value

9 in binders based on alkali aluminosilicate hydrate, were evaluated as described in the following.

10 The loss-on-ignition (LOI) of biomass ashes after combustion ranged from 6.8 to $18 \%$. The LOI values

11 after exposure to elevated temperature $550^{\circ} \mathrm{C}$ for 4 hours in furnace were less than $5 \%$.

12 Figure 2 shows SEM images of non-wood biomass ashes after similar combustion and size reduction 13 processes. The ash particles are of irregular shape with curved or angular morphologies. Finer particles 14 seem to have adhered to coarser particles, which could have resulted from condensation on coarser 15 particles during the process of ash formation; this observation could also be caused partly by the size 16 reduction process.

20 The particle size distributions for different non-wood biomass ashes are presented in Figure 3, and the 21 values of mean particle size $\left(D_{50}\right)$ are presented in Table 7 . The values of mean particle size vary from 9.6 22 to $85 \mu \mathrm{m}$, which occur within the range of micrometer-scale cementitious materials. The larger mean 23 particle size of $85 \mu \mathrm{m}$, however, could produce slow rates of hydration reactions. 
3 The measured values of $\mathrm{pH}$ are presented in Table 8 for different non-wood biomass ashes. The $\mathrm{pH}$ test

4 results of Table 8 indicate that the high alkali metal content of the non-wood biomass ash yields highly

5 alkaline solutions. This was a primary consideration in selection of the specific (alkali aluminosilicate

6 hydrate) binder chemistry considered in this development effort, which can make beneficial use of the

7 high alkali content of non-wood biomass ash. The test results presented in Table 8 further indicate that the

8 alkalinity of non-wood biomass ash is dependent upon the biomass species; the lowest $\mathrm{pH}$ is obtained

9 with rice hull ash (10.11 at 2 wt.\% and 10.50 at 5 wt.\%), and the highest with corn cob ash (12.42 at 2 wt.\% and 12.60 at 5 wt.\%). It should be emphasized that the high alkalinity of solutions containing nonwood biomass ash favors their value-added use in alkali aluminosilicate hydrate binder. The range of alkalinity covered by biomass ash also implies that the binder composition should be tailored towards the type of biomass ash.

$<$ Table 8>

17 Table 9 compares the degrees of dissolution of different non-wood biomass ashes as well as that of coal fly ash after different periods of immersion in $10 \mathrm{M} \mathrm{NaOH}$ solution. The degrees of dissolution of nonwood biomass ashes are generally higher than that of coal fly ash, except for switch-grass ash (5.98\%

20 after 60 min compared to $7.78 \%$ for coal ash). Cotton cob ash produced the highest degree of dissolution 21 after $60 \mathrm{~min}(24.76 \%)$. The data presented in Table 9 indicates that ashes from various non-wood biomass 22 species exhibit different degrees of dissolution in alkaline solution, which could impact the rate (and the 23 extent) of strength development in upon hydration. 
1 Elemental analysis was performed on the non-wood biomass ashes (Table 10). Some important features

2 of the wheat straw ash that are relevant to its use in geopolymerization include relatively high $\mathrm{SiO}_{2}$ and

$3 \quad \mathrm{~K}_{2} \mathrm{O}$ contents, and relatively low calcium and aluminum contents. Alfalfa, cotton stalk and cotton gin

4 show low $\mathrm{SiO}_{2}$ and $\mathrm{Al}_{2} \mathrm{O}_{3}$ with highly $\mathrm{K}_{2} \mathrm{O}$ content. The rice hull ash shows high $\mathrm{SiO}_{2}$ content (more than

$590 \%$ ) with small percentage of $\mathrm{K}_{2} \mathrm{O}$. This characteristic chemical composition suits alkali activation and

6 geopolymerization as far as the non-wood biomass ash is blended with alumina-rich constituents (e.g.,

7 coal fly ash, slag, metakaolin). The high alkali content of non-wood biomass ash plays the favorable

8 activation role in the course of geopolymerizaiton.

9

10

11

12 Figure 4 shows the XRD patterns of non-wood biomass ashes. These patterns were evaluated in order to

13 identify the mineral phases present in the ash samples. The XRD patterns of the ash samples exhibit

14 similar peaks. Rice hull ash exhibits an amorphous structure with a broad peak around silica, which points

15 at the prevalence of amorphous silica in the rice hull ash structure. Wheat straw ash exhibits a generally

16

17 peaks associated with crystalline sylvite. Cotton cob and cotton gin ashes exhibit more crystalline

18

19

20

21

22

23

24
$<$ Table 10> oxide. Cotton stalk ash exhibits a crystalline structure with peaks associated with quartz, calcite, sylvite and sodium aluminum oxide. Among the three cotton residues, cotton cob ash exhibits some amorphous patterns with a broad peak around calcite, sylvite and quartz peaks. Alfalfa ash exhibits a crystalline structure with peaks corresponding to quartz, calcite, sylvite and calcium silicate. Finally, the switchgrass ash exhibits an amorphous structure marked by a broad peak around calcite and quartz peaks, with few crystalline species among which only sodium aluminum oxide could be identified. 
1 Analysis of the XRD data (Figure 4) yielded the degrees of crystallinity of different non-wood biomass

2 ashes. Table 11 presents the degrees of crystallinity of different biomass ashes as well as that of a coal fly

3 ash. The results confirm the findings of Figure 4, indicating that alfalfa, cotton stalk and cotton gin ashes

4 have relatively high degrees of crystallinity, and wheat straw and rice hull ashes provide relatively low

5 degrees of crystallinity. The coal fly ash considered here provides a relatively low degree of crystallinity.

6 The above analysis of XRD patterns points at the differences between the degrees of crystallinity and the

7 mineral composition of different biomass ashes. There is, however, no clear correlation between the

8 degree of crystallinity and the extent of dissolution of biomass ash in alkaline solution or their $\mathrm{pH}$ in

9 solution. Consideration of particle size of different non-wood biomass ashes also does not help with

10 establishing such correlations. The concentration of defects in crystalline structures and the relative 11 solubility of various minerals could explain the lack of such correlations.

$<$ Figure 4>

$<$ Table 11>

\section{Experimental results: wheat straw ash-based geopolymer concrete materials}

18 The effect of $\mathrm{NaOH}$ concentration on the compressive strength of concrete incorporating wheat straw ash

19 is presented in Figure 5. There is some gain in compressive strength with increasing concentration of

$20 \mathrm{NaOH}$ in solution. Compressive strengths range from 50 to $60 \mathrm{MPa}$, which are higher than those provided 21 by normal-strength Portland cement concrete.

22 
1 The test data generated in the optimization experimental program is presented in Table 12. Figure 6

2 shows some trends reflecting the effects of design variables on the compressive strength test results in the

3 optimization experimental program. Compressive strength is found to be most sensitive to water-to-solid

4 ratio, which could be explained by the rise in porosity and probably the drop in $\mathrm{pH}$ with increasing water

5 content. There is a relatively small effect of (solid) activator-to-ash ratio on compressive strength,

6 indicating that compressive strength peaks at a medium activator-to-ash ratio of 0.27 . Compressive

7 strength seems to be insensitive to the variations in (solid) sodium silicate-to-sodium hydroxide ratio

8 within the range considered in the optimization experimental program. This could be due to the relatively

9 high available silica content of non-wood biomass ash. The response surfaces developed using the 10 compressive strength test data gene are presented in Figure 7. Response surface (Ridge) analysis of the 11 compressive strength test data yielded the following optimum levels (at 95\% confidence) of design 12 variables for the geopolymer concrete material incorporating wheat straw ash:

Effects of the mix design variables in the optimization test program on the (initial) set time and fresh mix

24 flow of geopolymer concrete are presented in Figures 8 and 9, respectively. The set time test results 25 indicate that increasing the (solid) activator-to-ash ratio consistently increases the set time of geopolymer 
concrete incorporating wheat straw ash. The set time of geopolymer concrete tends to be higher at an

2 intermediate level of solid sodium silicate-to-sodium hydroxide ratio. The increase in water-to-solid ratio

3 first decreases and then increases the initial set time of geopolymer concrete incorporating wheat straw

4 ash. The solid activator-to-ash ratio plays a significant role in controlling the initial set time of the

5 geopolymer mixture. The increase in set time with increasing solid activator-to-ash ratio might be due to

6 the consequent rise in $\mathrm{SiO}_{2}$ content (and thus the $\mathrm{SiO}_{2} / \mathrm{Al}_{2} \mathrm{O}_{3}$ ratio). It has been found that the set time of

7 low-calcium geopolymer systems is controlled by the $\mathrm{Al}_{2} \mathrm{O}_{3}$ content, with set time increasing at higher

$8 \mathrm{SiO}_{2} / \mathrm{Al}_{2} \mathrm{O}_{3}$ ratios [29]. The fresh mix flow of geopolymer concrete increases consistently with increasing

9 (solid) sodium silicate-to-sodium hydroxide ratio. Unlike Portland cement concrete, the fresh mix flow of

10 geopolymer concrete seems to be insensitive to water-to-solid ratio within the range considered in the

11 optimization experimental program. Flow is also observed to peak at an intermediate level of solid

12 activator-to-ash ratio. The sodium silicate-to-sodium hydroxide ratio seems to be a key factor influencing

13 the workability of fresh non-wood biomass ash-based geopolymer concrete. The improved workability

14 obtained at higher sodium silicate-to-sodium hydroxide ratios could be explained by the consequent drop

15 in $\mathrm{Na}_{2} \mathrm{O}$ concentration which lowers the fresh viscosity and increases the flow diameter [30]. Also, the

16 addition of sodium silicate makes extra soluble silicates available, raising the $\mathrm{SiO}_{2} / \mathrm{Al}_{2} \mathrm{O}_{3}$ ratio towards

17 and optimum level which yields improvements in both the fresh mix workability and the hardened 18 material density and strength [31].

$<$ Figure 8>

$<$ Figure 9>

\subsection{Moisture stability of alkali-activated non-wood biomass ash-based concrete}

24 It was noticed that alkali-activated non-wood biomass ash concrete exhibits signs of cracking and 25 deteriorations after immersion in boiling $\left(100^{\circ} \mathrm{C}\right)$ water (Figure 10). Compression tests indicated that $75-$ 
$180 \%$ of compressive strength is lost after immersion in boiling water. As shown in Figure 11, unlike the

2 geopolymer concrete based on biomass ash, that based on coal fly ash experienced a rise in compressive

3 strength after immersion in boiling water. Moisture resistance is a key feature of concrete; an extensive

4 effort was undertaken in order to refine the biomass ash-based concrete chemistry for realizing the high

5 levels of moisture resistance required for its successful transition to construction markets.

6

7

8

9

10

11 The geopolymerization process involves dissolution of aluminosilicate precursors in an alkaline solution,

12 which are then condensed and further polycondensed to form an extended 3D structure which exhibits

13 high levels of moisture resistance and durability. Intermediate condensation steps can yield solids

14 consisting of relatively small aluminosilicate and sodium silicate molecules with high compressive

15 strength. These solids, however, lack adequate resistance against deterioration in moist environments.

16 High levels of moisture resistance can be realized if the chemistry of solution in fresh mix favors

17 advancement of the geopolymerization process through the polycondensation step which yields stable 3D

18 networked structures.

19 The steps involved in the geopolymerization process comprise three main stages of dissolution, 20 condensation and polycondensation. The chemistry of solution, including the balance of $\mathrm{Al}, \mathrm{Si}$ and $\mathrm{Na}$ (or

$21 \mathrm{~K}$ ) in dissolved compounds, determine if the process concludes with polycondensation of 3D alkali

22 aluminosilicate species which are moisture-resistant, or stops at the condensation step, yielding relatively

23 small molecules which are susceptible to moisture attack due to the dissolution of the alkali cations

24 exposed on their exterior. The mineralogy of mix ingredients (including biomass ash) determines the

25 composition of dissolved species in fresh mixture, and the potential for proceeding through initial 
condensation to conclude the polycondensation step which is required for realizing high levels of

2 moisture resistance.

3 The non-wood biomass (wheat straw) ash is used primarily as a source of siliceous and alkali constituents

4 for production of geopolymer concrete. This composition is supplemented with other waste constituents

5 (e.g., coal fly ash) to introduce adequate aluminous compounds. However, one cannot ensure achievement

6 of a desired chemical balance in solution by simply balancing the solid chemistry. The solubility of

7 minerals present in solid compounds determines if a desired chemical balance in solids would translate

8 into a desired solution chemistry. Moisture-sensitivity of the early generation of alkali-activated biomass

9 ash-based concrete indicates that a desired chemical balance in solution was not realized, and the process

10 stopped at the initial condensation stage which yields a high level of compressive strength but inadequate

11 moisture resistance. An extensive trial-and-adjustment approach was undertaken in order to refine the

12 chemistry of solution to enable progress through the polycondensation step to yield a moisture-resistant

13 3D networked structure.

14 The original binder composition comprised 50\% biomass ash and 50\% coal fly ash. After several trials, it

15 was found that a binder comprising 50\% biomass ash, 25\% metakaolin and 25\% coal fly ash enables

16 progress of the geopolymerization reactions through the polycondensation step. This could be due to the

17 desired aluminosilicate chemistry formed in the solution. Furthermore, it was found that addition of a

18 relatively low percentage of calcium sulfate hemi-hydrate (gypsum) to the mix benefits formation of a

19 moisture-resistant geopolymer structure. Past experience [32] has indicated that exterior ions raise the

20 leaching of alumina from the source materials to form additional aluminosilicates, and to increase the

21 concentration of calcium to form additional calcium silicate hydrate. The addition of gypsum could also

22 reduce the total porosity of end products; the greatest drop in total porosity was realized with the addition

23 of gypsum at $5 \%$ by weight of total ash (Figure 12).

24 


\section{Conclusions}

2 The value of diverse categories of non-wood biomass combustion ash as raw materials for production of 3 an alternative cementitious binder for concrete production was evaluated. The key findings of the project 4 are summarized below.

1. Cementitious binders based on alkali aluminosilicate hydrates can make value-added use of two major constituents of non-wood biomass combustion ash: silica and alkali metal (potassium) cations.

2. Thorough characterization of seven different non-wood biomass ashes, covering their chemical composition, mineralogy, degree of crystallinity, solubility, alkalinity, morphology and particle size distribution, indicated that they all offer viable attributes for use as raw materials in production of binders based on alkali aluminosilicate hydrates for concrete production.

3. Non-wood biomass ash-based binder compositions supplemented with alumina-rich constituents (e.g., coal fly ash) can be formulated to yield a desired chemical balance for production of highquality binders in concrete production. The relatively low calcium content of the formulations considered here imply that alkali aluminosilicate hydrates could have been formed probably in combination with secondary binders comprising calcium silicate hydrates. A systematic approach was developed and verified for formulation of inorganic binders which make value-added and large-volume use of non-wood biomass ash.

4. Non-wood biomass combustion ash can be formulated into cementitious binders for production of concrete materials with a desired balance of strength and moisture resistance. Care should be taken to formulate binders with a desired chemical balance in the dissolved matter at early age, which advance the hydration process through the critical polycondensation step. The result is a networked alkali aluminosilicate hydrate structure which exhibits a high degree of stability under hydrothermal effects. 


\section{Acknowledgment}

2 The authors are thankful to the United States Department of Agriculture for financial support of this work 3 under Award No. 2014-33610-21903.

4

$5 \quad$ References

6 1. Perlack, R.D., et al., Biomass as feedstock for a bioenergy and bioproducts industry: the technical 7 feasibility of a billion-ton annual supply. 2005, DTIC Document.

8 2. Bruhn, A., et al., Bioenergy potential of Ulva lactuca: Biomass yield, methane production and combustion. Bioresource Technology, 2011. 102(3): p. 2595-2604.

10 3. Gartner, E., Industrially interesting approaches to "low-CO2" cements. Cement and Concrete Research, 2004. 34(9): p. 1489-1498.

12 4. Ban, C. and R. Mahyuddin, Properties of high calcium wood ash and densified silica fume 13 blended cement. International Journal of Physical Sciences, 2011. 6(28): p. 6596-6606.

$145 . \quad$ Esteves, T.C., et al., Use of biomass fly ash for mitigation of alkali-silica reaction of cement 15 mortars. Construction and Building Materials, 2012. 26(1): p. 687-693.

16 6. Wang, S., L. Baxter, and F. Fonseca, Biomass fly ash in concrete: SEM, EDX and ESEM 17 analysis. Fuel, 2008. 87(3): p. 372-379.

18 7. Zhou, S., X. Zhang, and X. Chen, Pozzolanic activity of feedlot biomass (cattle manure) ash. 19 Construction and Building Materials, 2012. 28(1): p. 493-498.

20 8. Turner, L.K. and F.G. Collins, Carbon dioxide equivalent (CO 2-e) emissions: a comparison 21 between geopolymer and OPC cement concrete. Construction and Building Materials, 2013. 43: $22 \quad$ p. $125-130$.

23 9. Provis, J.L., A. Palomo, and C. Shi, Advances in understanding alkali-activated materials. 24 Cement and Concrete Research, 2015. 78: p. 110-125. 
1 10. Pacheco-Torgal, F., et al., Handbook of Alkali-Activated Cements, Mortars and Concretes. 2014, $2 \quad$ Cambridge: Woodhead publishing.

3 11. Davidovits, J., Geopolymer Chemistry and Applications. 3 ed. 2011: Geopolymer Institute.

4 12. Skibsted, J. and M.D. Andersen, The Effect of Alkali Ions on the Incorporation of Aluminum in 5 the Calcium Silicate Hydrate (C-S-H) Phase Resulting from Portland Cement Hydration Studied 6 by Si-29 MAS NMR. Journal of the American Ceramic Society, 2013. 96(2): p. 651-656.

7 13. Provis, J.L., Geopolymers and other alkali activated materials: why, how, and what? Materials $8 \quad$ and Structures, 2014. 47(1-2): p. 11-25.

9 14. Lancellotti, I., et al., Inorganic polymers from alkali activation of metakaolin: Effect of setting 10

11 15. Komnitsas, K. and D. Zaharaki, Geopolymerisation: A review and prospects for the minerals industry. Minerals Engineering, 2007. 20(14): p. 1261-1277.

13 16. Majidi, B., Geopolymer technology, from fundamentals to advanced applications: a review. Materials Technology, 2009. 24(2): p. 79-87.

15 17. Pacheco-Torgal, F., et al., Durability of alkali-activated binders: A clear advantage over Portland cement or an unproven issue? Construction and Building Materials, 2012. 30: p. 400405.

18. Pacheco-Torgal, F., J. Castro-Gomes, and S. Jalali, Alkali-activated binders: A review - Part 1. Historical background, terminology, reaction mechanisms and hydration products. Construction and Building Materials, 2008. 22(7): p. 1305-1314.

19. Shaikh, F.U.A., Review of mechanical properties of short fibre reinforced geopolymer composites. Construction and Building Materials, 2013. 43: p. 37-49.

20. Van Deventer, J.S., J.L. Provis, and P. Duxson, Technical and commercial progress in the adoption of geopolymer cement. Minerals Engineering, 2012. 29: p. 89-104.

21. Lloyd, R.R., J.L. Provis, and J.S. Van Deventer, Pore solution composition and alkali diffusion in 26 inorganic polymer cement. Cement and Concrete Research, 2010. 40(9): p. 1386-1392. 
$122 . \quad$ Biedermann, F. and I. Obernberger. Ash-related problems during biomass combustion and 2 possibilities for a sustainable ash utilisation. in Proceedings of the International Conference 3 „World Renewable Energy Congress “(WREC), May, Aberdeen, Scotland, Elsevier Ltd., Oxford, $4 \quad$ UK. 2005.

5 23. Rajamma, R., J.A. Labrincha, and V.M. Ferreira, Alkali activation of biomass fly ash-metakaolin $6 \quad$ blends. Fuel, 2012. 98: p. 265-271.

7 24. Chen-Tan, N.W., et al., Determining the Reactivity of a Fly Ash for Production of Geopolymer. 8 Journal of the American Ceramic Society, 2009. 92(4): p. 881-887.

$9 \quad 25 . \quad$ C642, A., Density absorption and voids in hardened concrete. 2006.

10 26. Alvarez-Ayuso, E., et al., Environmental, physical and structural characterisation of geopolymer 11 matrixes synthesised from coal (co-)combustion fly ashes. Journal of Hazard Materials, 2008. $12 \quad \mathbf{1 5 4}(1-3):$ p. $175-83$.

13 27. Olivia, M. and H. Nikraz, Properties of fly ash geopolymer concrete designed by Taguchi 14 method. Materials \& Design, 2012. 36: p. 191-198.

15 28. Bondar, D., C.J. Lynsdale, and N.B. Milestone, Alkali-Activated Natural Pozzolan Concrete as $16 \quad$ New Construction Material. ACI Materials Journal, 2013.

17 29. De Silva, P. and K. Sagoe-Crenstil, The effect of Al 2 O 3 and SiO 2 on setting and hardening of $18 \mathrm{Na} 2 \mathrm{O}-\mathrm{Al} 2 \mathrm{O}$ 3-SiO 2-H 2 O geopolymer systems. J Aust Ceram Soc, 2008. 44(1): p. 39-46.

$1930 . \quad$ Ghosh, K. and P. Ghosh, Effect Of Na2O/Al2O3, SiO2/Al2O3 and w/b ratio on setting time and 20

22 31. Douglas, E., et al., Alkali activated ground granulated blast-furnace slag concrete: preliminary investigation. Cement and concrete research, 1991. 21(1): p. 101-108.

24 32. Boonserm, K., et al., Improved geopolymerization of bottom ash by incorporating fly ash and 25 using waste gypsum as additive. Cement and Concrete Composites, 2012. 34(7): p. 819-824. 
1 
Table 1. Characteristics of typical wood, agricultural waste and algae combustion ashes [2, 3].

\begin{tabular}{|c|c|c|c|c|c|c|c|c|c|c|c|c|}
\hline \multirow{2}{*}{ Biomass } & \multirow{2}{*}{$\begin{array}{l}\text { Ash, wt. } \% \text { of } \\
\text { fuel }\end{array}$} & \multicolumn{11}{|c|}{ Ash composition (wt.\% of ash) } \\
\hline & & $\mathrm{CaO}$ & $\mathrm{SiO}_{2}$ & $\mathrm{Al}_{2} \mathrm{O}_{3}$ & $\mathrm{Na}_{2} \mathrm{O}$ & $\mathrm{K}_{2} \mathrm{O}$ & $\mathrm{Fe}_{2} \mathrm{O}_{3}$ & $\mathrm{MgO}$ & $\mathrm{Cl}$ & $\mathrm{SO}_{3}$ & $\mathrm{P}_{2} \mathrm{O}_{5}$ & $\mathrm{GCV}^{(\mathrm{a})}$ \\
\hline Wood & 0.4 & 30 & 7 & 1 & 1 & 8 & 1 & 6 & 2 & 10 & 5 & 21 \\
\hline Wheat straw & 6 & 7 & 52 & 3 & 2 & 23 & 1 & 2 & 6 & 9 & 3 & 19 \\
\hline Ulva lactuca (algae) & 35 & 8 & 24 & 0 & 8 & 11 & 2 & 12 & 9 & 19 & 4 & 13 \\
\hline
\end{tabular}

${ }^{\text {(a) }}$ Gross calorific value, $\mathrm{MJ} / \mathrm{kg}$ 
Table 2. Chemical compositions of ashes produced by combustion of some agricultural residues, algae, cattle manure and coal at the specified temperatures and durations [2, 9, 20-25].

\begin{tabular}{lcccccccccc}
\hline \multicolumn{1}{c}{ Residue } & $\mathrm{SiO}_{2} \%$ & $\mathrm{Al}_{2} \mathrm{O}_{3} \%$ & $\mathrm{Fe}_{2} \mathrm{O}_{3} \%$ & $\mathrm{CaO} \%$ & $\mathrm{MgO} \%$ & $\mathrm{Na}_{2} \mathrm{O} \%$ & $\mathrm{~K}_{2} \mathrm{O} \%$ & $\begin{array}{c}\text { LOI } \\
\begin{array}{c}\text { Combustion } \\
\mathrm{Temp} .\end{array}{ }^{\circ} \mathrm{C}\end{array} \begin{array}{c}\text { Combustion } \\
\mathrm{Time}, \mathrm{hr}\end{array}$ \\
\hline Corn cob & 66.4 & 7.5 & 4.4 & 11.6 & 2.1 & 0.4 & 4.9 & 1.4 & 650 & 8 \\
\hline Wheat straw & 54.2 & 4.6 & 1.1 & 12.5 & 2.4 & $\mathrm{NA}$ & $\mathrm{NA}$ & 7.2 & 670 & 5 \\
\hline Vetiver grass & 57.5 & 3.7 & 1.7 & 5.5 & 1.2 & 0.1 & 15.5 & 12 & 900 & 9 \\
\hline Rice husk & 93.2 & 0.4 & 0.1 & 1.1 & 0.1 & 0.1 & 1.3 & 3.7 & 650 & NA \\
\hline Oil palm shell & 63.6 & 1.6 & 1.4 & 7.6 & 3.9 & 0.1 & 6.9 & 9.6 & NA & NA \\
\hline Cotton stalk & 51.1 & 9.4 & 3.8 & 12.3 & 3.7 & 2.4 & 11.7 & $\mathrm{NA}$ & NA & NA \\
\hline $\begin{array}{l}\text { Green } \\
\text { macroalgae }\end{array}$ & 23.5 & 0 & 1.5 & 8.3 & 12.4 & 7.8 & 10.4 & $\mathrm{NA}$ & NA & NA \\
\hline Cattle manure & 52 & 7.8 & 3.2 & 15.4 & 2.9 & 0.7 & 4.9 & 2.5 & NA & NA \\
\hline Coal fly ash & 55.2 & 19 & 5.2 & 3.6 & 1.7 & 0.5 & 1.3 & 1 & NA & NA \\
\hline NA = Not available in the reference reporting the chemical composition & & & &
\end{tabular}


Table 3. Chemical composition of the coal fly ash and metakaolin, weight $\%$.

\begin{tabular}{lcccccc}
\hline & $\mathrm{SiO}_{2}$ & $\mathrm{CaO}$ & $\mathrm{Al}_{2} \mathrm{O}_{3}$ & $\mathrm{~K}_{2} \mathrm{O}$ & $\mathrm{Na}_{2} \mathrm{O}$ & LOI \\
\hline Coal fly ash & 43.1 & 14.3 & 23.3 & 1.7 & 0.9 & 1.7 \\
Metakaolin & 52.5 & 0.04 & 44.4 & 0.15 & 0.25 & 0.6 \\
\hline
\end{tabular}


Table 4. Particle size distributions of the coarse and fine aggregates.

\begin{tabular}{ccc}
\hline \multirow{2}{*}{ Size, $\mathrm{mm}$} & \multicolumn{2}{c}{ \% Passing } \\
\cline { 2 - 3 } & Coarse aggregate & Fine aggregate \\
\hline 0.15 & 0.00 & 1.56 \\
\hline 0.30 & 0.00 & 6.77 \\
\hline 0.60 & 0.00 & 36.93 \\
\hline 1.18 & 1.01 & 64.54 \\
\hline 2.36 & 6.13 & 92.10 \\
\hline 4.75 & 21.67 & 100.00 \\
\hline 9.50 & 99.48 & 100.00 \\
\hline 12.50 & 100.00 & 100.00 \\
\hline
\end{tabular}


Table 5. Mix proportions of wheat straw ash-based concrete.

\begin{tabular}{lc}
\hline \multicolumn{1}{c}{ Material } & Quantity, $\mathrm{Kg} / \mathrm{m}^{3}$ \\
\hline Coal fly ash & 247 \\
\hline Biomass ash & 247 \\
\hline Fine aggregate & 691 \\
\hline Coarse aggregate & 858 \\
\hline Sodium silicate solution & 123.5 \\
\hline NaOH solution & 123.5 \\
\hline Activator solution/Ash & 0.6 \\
\hline
\end{tabular}


Table 6. The variables and their levels considered in the optimization experimental program.

\begin{tabular}{ccccc}
\hline & Variable & Level -1 & Level 0 & Level 1 \\
\hline $\mathrm{A}$ & Solid activator-to-ash ratio & 0.23 & 0.27 & 0.31 \\
\hline $\mathrm{B}$ & Solid $\mathrm{Na}_{2} \mathrm{SiO}_{3}$-to-NaOH ratio & 1.00 & 1.50 & 2.00 \\
\hline $\mathrm{C}$ & Water-to-solid ratio* & 0.27 & 0.3 & 0.33 \\
\hline
\end{tabular}

*Total Solid includes solid $\mathrm{Na} 2 \mathrm{SiO} 3$, solid $\mathrm{NaOH}$, and ash. 
Table 7. Mean particle sizes of different non-wood biomass ashes.

\begin{tabular}{lc}
\hline Non-wood biomass ash & Mean particle size, $\mu \mathrm{m}\left(\mathrm{D}_{50}\right)$ \\
\hline Wheat straw ash & 9.6 \\
\hline Switch-grass ash & 21.4 \\
\hline Alfalfa ash & 15.6 \\
\hline Corn cob ash & 19.5 \\
\hline Rice hull ash & 9.35 \\
\hline Cotton stalk ash & 24.5 \\
\hline Cotton gin ash & 85.0 \\
\hline
\end{tabular}


Table 8. Measured values of $\mathrm{pH}$ for biomass ashes at different concentrations in deionized water.

\begin{tabular}{lcc}
\hline Non-wood Biomass Ash & $\mathrm{pH} 2$ wt.\% & $\mathrm{pH} \mathrm{5} \mathrm{wt. \%}$ \\
\hline Wheat straw ash & 10.98 & 11.10 \\
\hline Switch grass ash & 12.07 & 12.15 \\
\hline Alfalfa ash & 11.93 & 11.98 \\
\hline Corn cob ash & 12.42 & 12.60 \\
\hline Rice hull ash & 10.11 & 10.50 \\
\hline Cotton stalk ash & 12.08 & 12.33 \\
\hline Cotton gin ash & 11.91 & 12.11 \\
\hline
\end{tabular}


Table 9. Extents of dissolution of coal fly ash versus biomass ashes.

\begin{tabular}{lccc}
\hline Ash Type & $15 \mathrm{~min}$ & $30 \mathrm{~min}$ & $60 \mathrm{~min}$ \\
\hline Coal fly ash & $5.28 \%$ & $5.98 \%$ & $7.78 \%$ \\
\hline Wheat straw ash & $2.91 \%$ & $6.01 \%$ & $11.95 \%$ \\
\hline Switch grass ash & $3.34 \%$ & $5.45 \%$ & $5.98 \%$ \\
\hline Alfalfa ash & $8.53 \%$ & $13.46 \%$ & $19.20 \%$ \\
\hline Corn cob ash & $8.20 \%$ & $10.22 \%$ & $24.76 \%$ \\
\hline Rice hull ash & Not Available & Not Available & Not Available \\
\hline Cotton stalk ash & $8.81 \%$ & $14.28 \%$ & $22.09 \%$ \\
\hline Cotton gin ash & $11.33 \%$ & $16.12 \%$ & $24.49 \%$ \\
\hline
\end{tabular}


Table 10. Chemical compositions obtained via XRF analysis and LOI values of the biomass ashes(wt.\%).

\begin{tabular}{cccccccccc}
\cline { 2 - 9 } & $\mathrm{SiO}_{2}$ & $\mathrm{CaO}$ & $\mathrm{Al}_{2} \mathrm{O}_{3}$ & $\mathrm{~K}_{2} \mathrm{O}$ & $\mathrm{MgO}$ & $\mathrm{P}_{2} \mathrm{O}_{5}$ & $\mathrm{Fe}_{2} \mathrm{O}_{3}$ & $\mathrm{SO}_{3}$ & LOI \\
\hline Wheat straw & 52.60 & 4.27 & 0.10 & 20.10 & 3.07 & 4.25 & 0.25 & 2.43 & 3.30 \\
\hline Alfalfa ash & 2.78 & 15.11 & 0.15 & 59.02 & - & 6.05 & 0.73 & 4.14 & 3.50 \\
\hline Corn cob & 13.69 & 18.35 & 0.74 & 47.82 & 5.40 & 4.22 & 4.71 & 2.51 & 3.30 \\
\hline Rice hull & 92.02 & 0.00 & 0.00 & 3.97 & - & - & - & 2.21 & 4.6 \\
\hline Cotton stalk & 3.66 & - & 0.80 & 31.37 & 7.40 & - & 2.20 & 5.42 & 9.80 \\
\hline Cotton gin & 4.47 & 23.15 & 0.57 & 47.63 & 4.20 & 4.00 & 1.75 & 7.21 & 7.25 \\
\hline
\end{tabular}


Table 11. The degrees of crystallinity for different biomass ashes and coal fly ash.

\begin{tabular}{lc}
\hline \multicolumn{1}{c}{ Ash } & \% of Crystallinity \\
\hline Coal fly ash & 32.9 \\
\hline Wheat straw ash & 34.9 \\
\hline Switch grass ash & 38.5 \\
\hline Alfalfa ash & 65.9 \\
\hline Corn cob ash & 49.2 \\
\hline Rice hull ash & 28.5 \\
\hline Cotton stalk ash & 63.8 \\
\hline Cotton gin ash & 72.7 \\
\hline
\end{tabular}


Table 12. Experimental results generated in the optimization test program.

\begin{tabular}{|c|c|c|c|c|c|c|c|}
\hline \multirow{2}{*}{ Mix no. } & \multicolumn{2}{|c|}{ Set time (Min) } & \multirow[t]{2}{*}{ Flow } & \multirow[t]{2}{*}{ Compressive strength (7- day) } & \multirow[t]{2}{*}{ Specific gravity } & \multirow{2}{*}{$\begin{array}{c}\text { Absorption } \\
\%\end{array}$} & \multirow{2}{*}{$\begin{array}{c}\text { Voids } \\
\%\end{array}$} \\
\hline & Initial & Final & & & & & \\
\hline 1 & 32 & 144 & 60 & 56.00 & 2.25 & 4.96 & 11.27 \\
\hline 2 & 62 & $>360$ & 66 & 51.00 & 2.21 & 5.50 & 8.14 \\
\hline 3 & 26 & 55 & 82 & 67.40 & 2.23 & 5.98 & 11.22 \\
\hline 4 & 59 & 125 & 86 & 54.91 & 2.22 & 5.93 & 11.65 \\
\hline 5 & 35 & 95 & 65 & 64.00 & 2.25 & 5.23 & 10.35 \\
\hline 6 & 85 & $>300$ & 52 & 73.75 & 2.23 & 4.99 & 10.70 \\
\hline 7 & 43 & 130 & 91 & 54.82 & 2.19 & 6.23 & 14.96 \\
\hline 8 & 72 & 240 & 81 & 56.40 & 2.20 & 5.58 & 11.45 \\
\hline 9 & 58 & 360 & 56 & 86.42 & 2.20 & 0.14 & 14.85 \\
\hline 10 & 53 & 62 & 135 & 61.40 & 2.25 & 4.97 & 10.37 \\
\hline 11 & 75 & $>330$ & 84 & 58.35 & 2.19 & 5.92 & 11.88 \\
\hline 12 & 35 & $\sim 75$ & 84 & 56.45 & 2.18 & 5.87 & 13.59 \\
\hline 13 & 50 & 158 & 70 & 61.30 & 2.21 & 5.62 & 12.39 \\
\hline 14 & 50 & 155 & 67 & 59.45 & 2.19 & 6.30 & 14.18 \\
\hline 15 & 48 & 150 & 70 & 64.00 & 2.23 & 5.32 & 10.68 \\
\hline
\end{tabular}




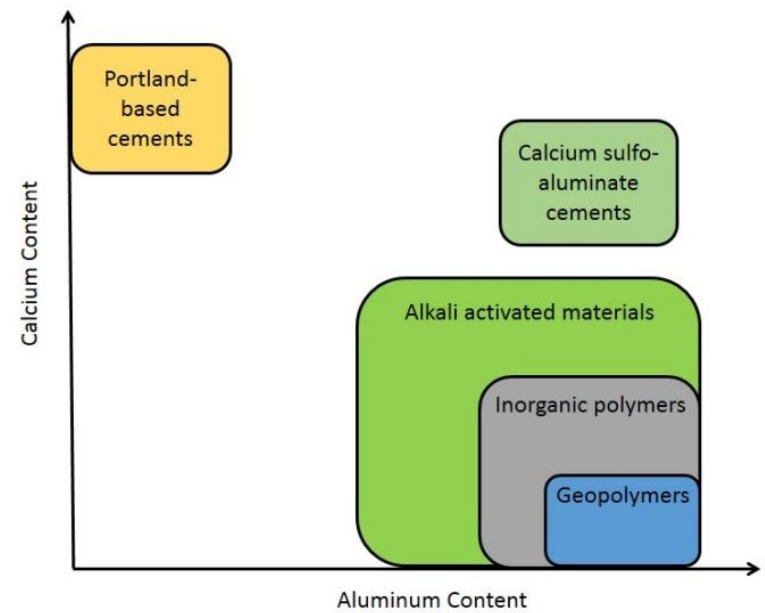

Figure 1. Classification of different subsets of alkali-activated materials, with comparisons to ordinary Portland cement and calcium sulfoaluminate binder chemistry (darker shading corresponds to higher concentrations of $\mathrm{Na}$ and/or K) [19]. 


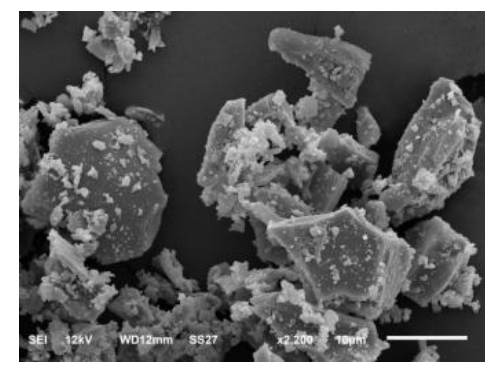

(a) Wheat straw ash

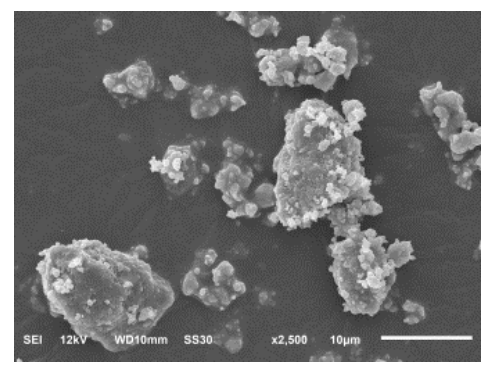

(b) Alfalfa ash

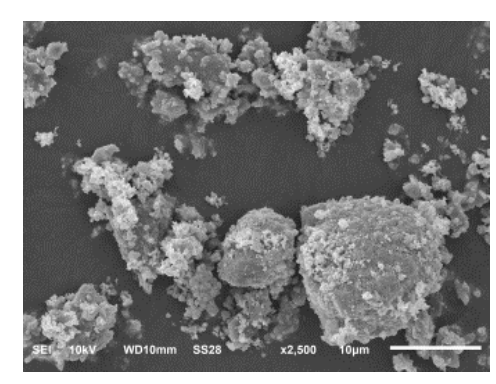

(d) Switch-grass ash

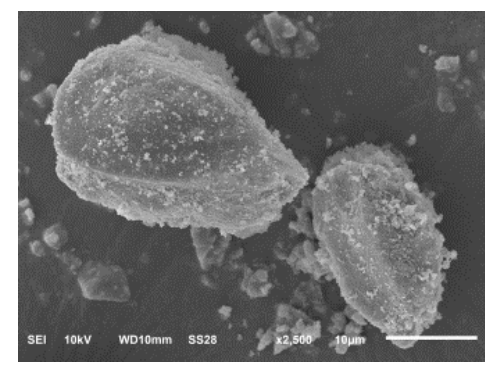

(c) Rice hull ash

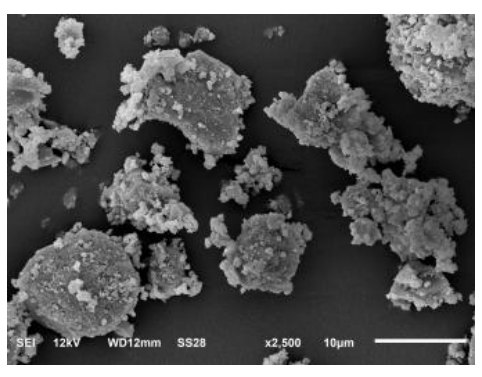

(e) Corn cob ash

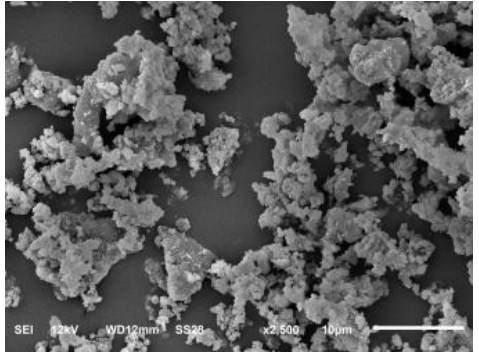

(f) Cotton stalk ash

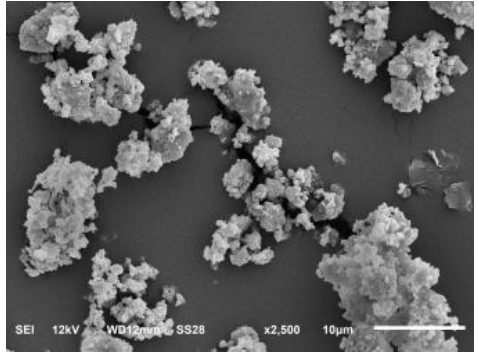

(g) Cotton gin ash

Figure 2. SEM images of different non-wood biomass ashes after size reduction. 


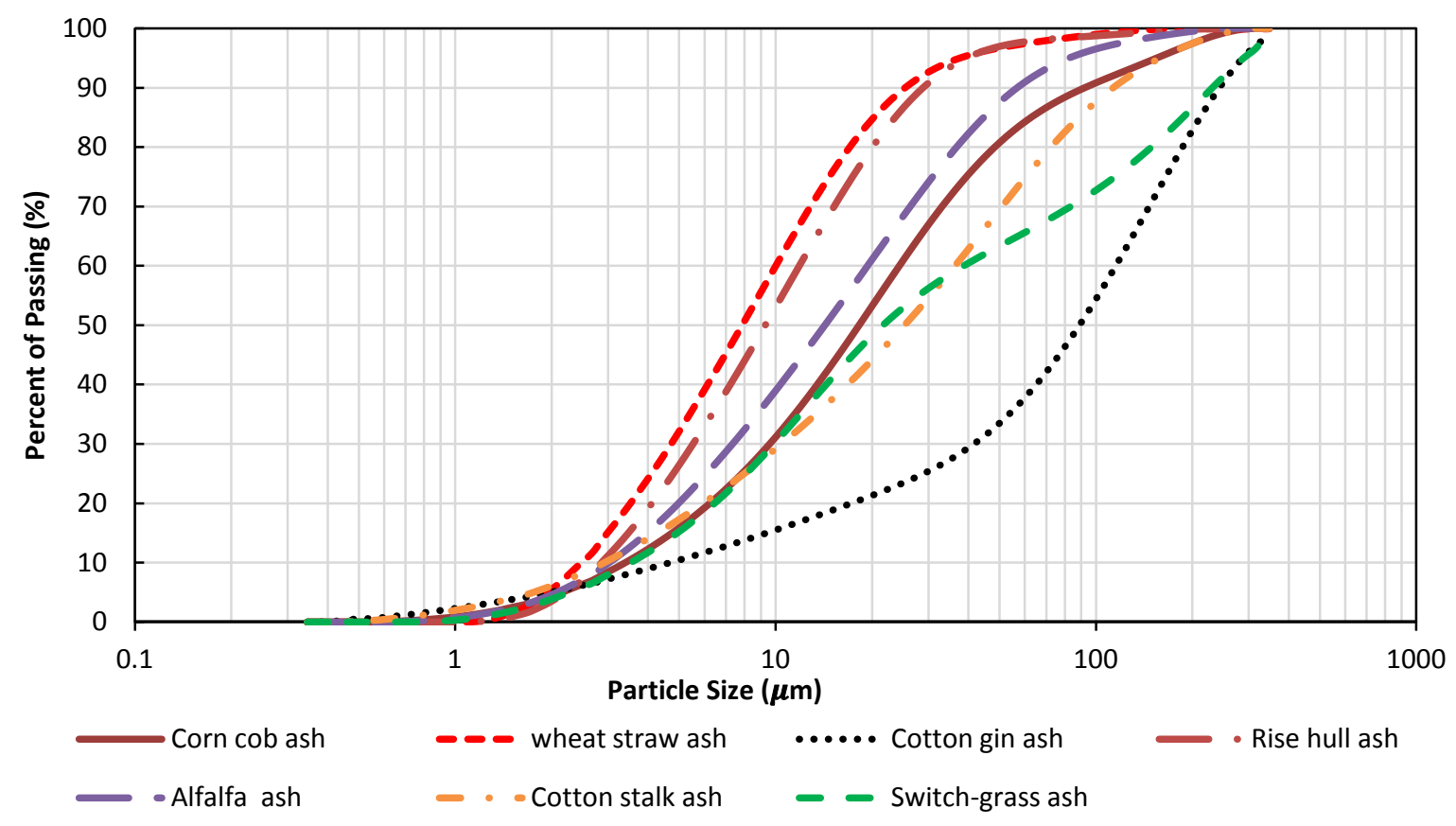

Figure 3. Particle size distributions of milled non-wood biomass ashes. 


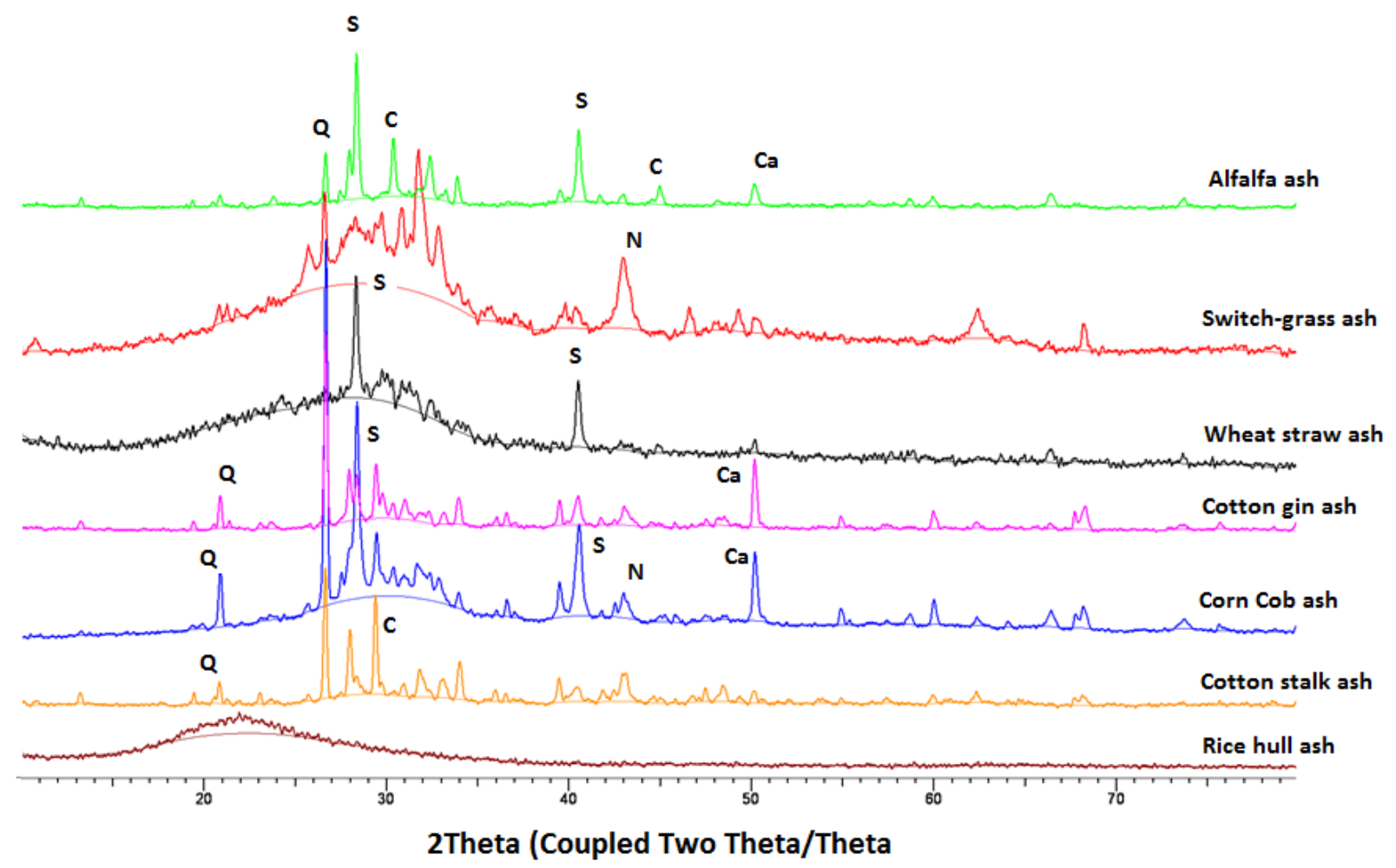

Figure 4. X-ray diffraction results for different non-wood biomass ashes.

Q: $\mathrm{SiO}_{2}$ (Quartz), C: $\mathrm{CaCO}_{3}$ (Calcite), Ca: Calcium silicates, N: sodium aluminum oxide, and S: $\mathrm{KCl}$

(Sylvite) 


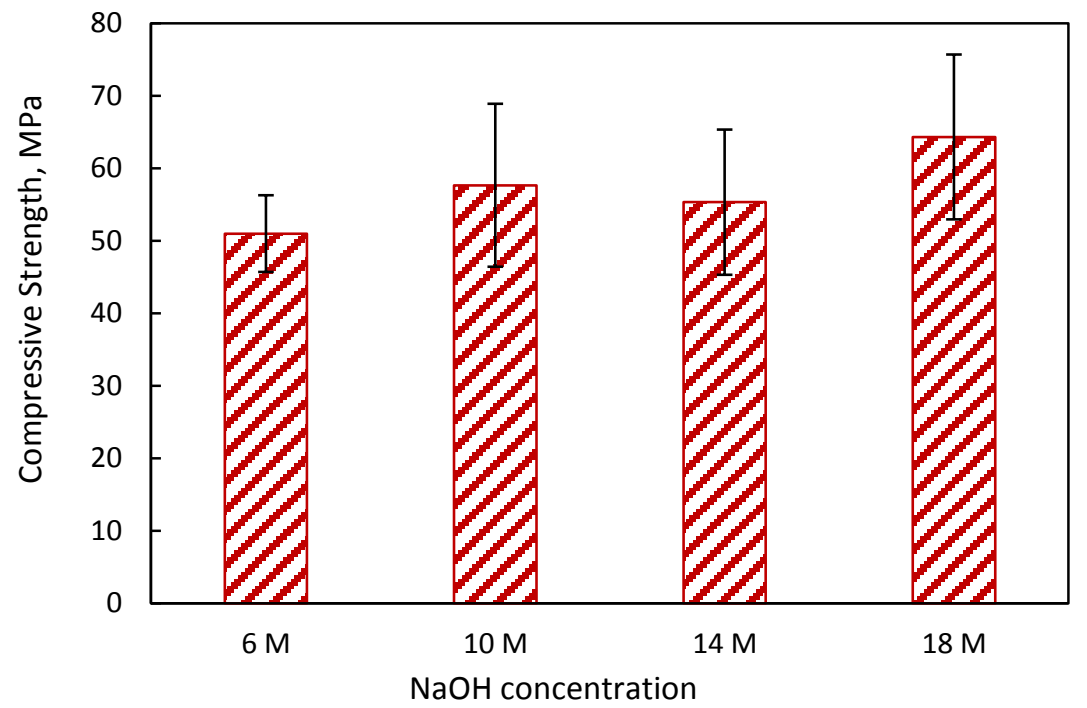

Figure 5. Effect of $\mathrm{NaOH}$ concentration on the seven-day compressive strength of geopolymer concrete (mean values and 95\% confidence intervals). 

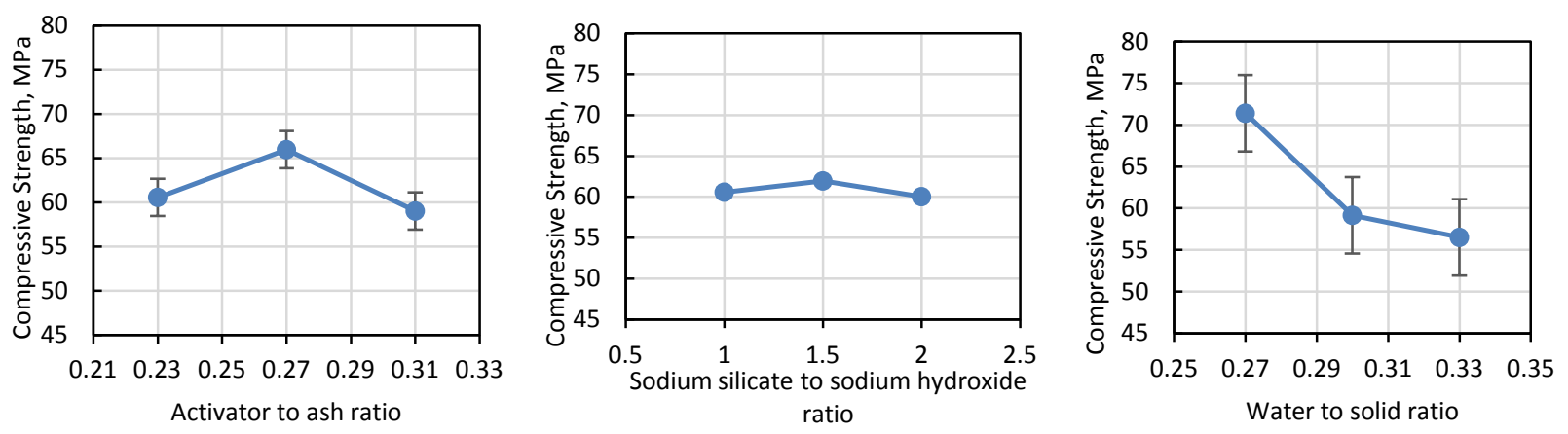

Figure 6. Effects of the optimization mix design variables on the compressive strength of geopolymer concrete materials incorporating non-wood biomass ash. 

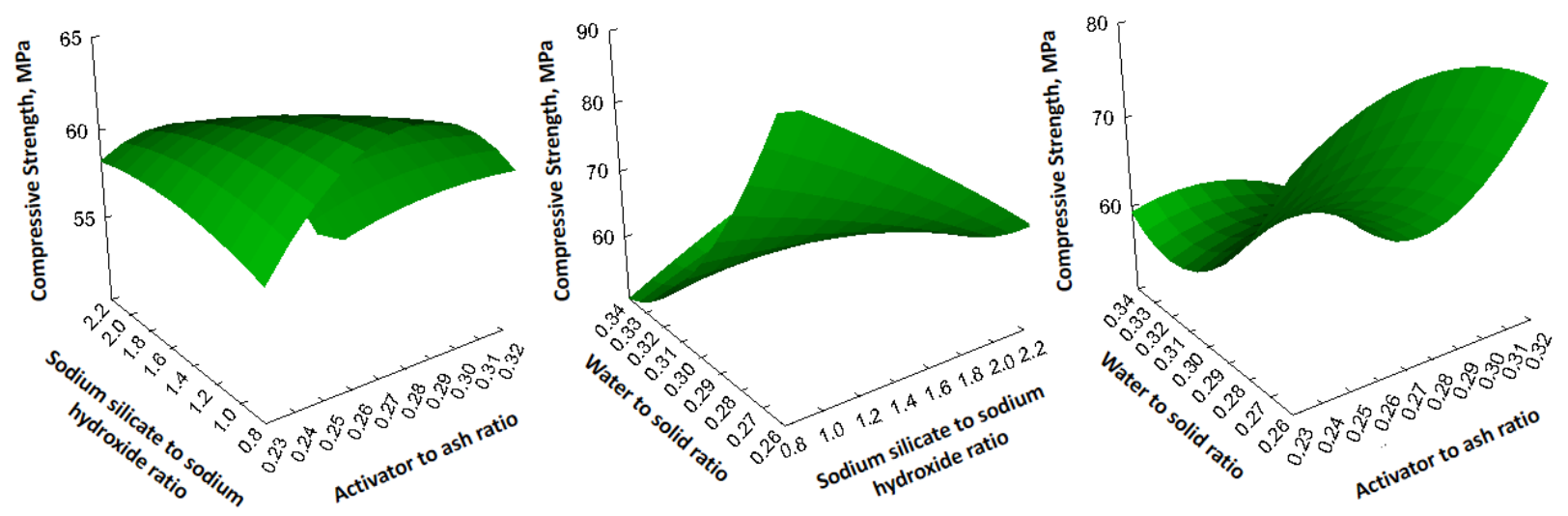

Figure 7. Response surfaces of the compressive strength test data generated in the optimization experimental program for the geopolymer concrete incorporating non-wood biomass ash. 

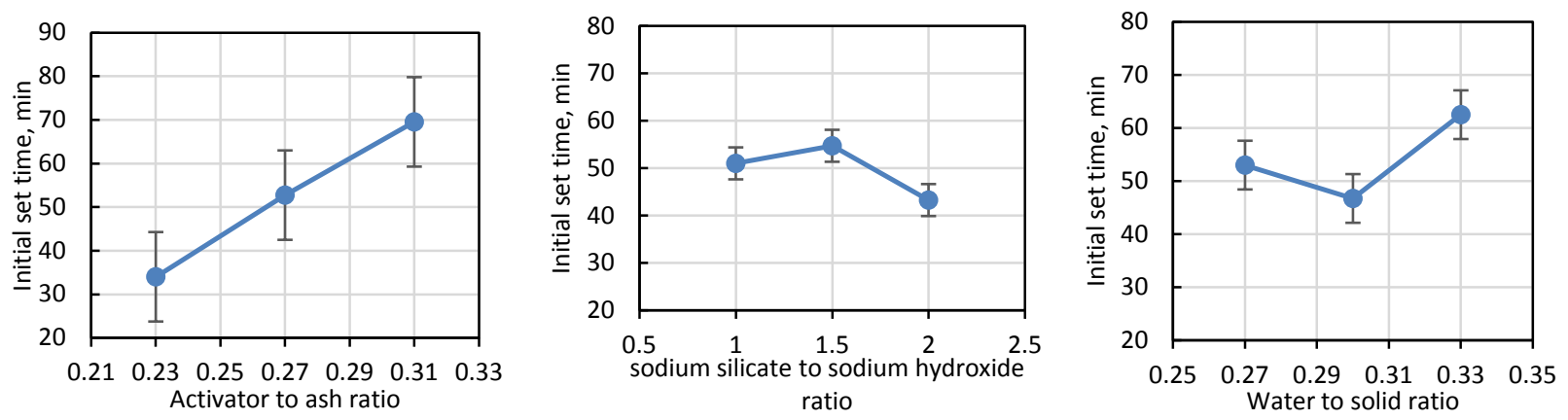

Figure 8. Effects of the optimization mix design variables on the initial set time of geopolymer concrete materials incorporating non-wood biomass ash. 

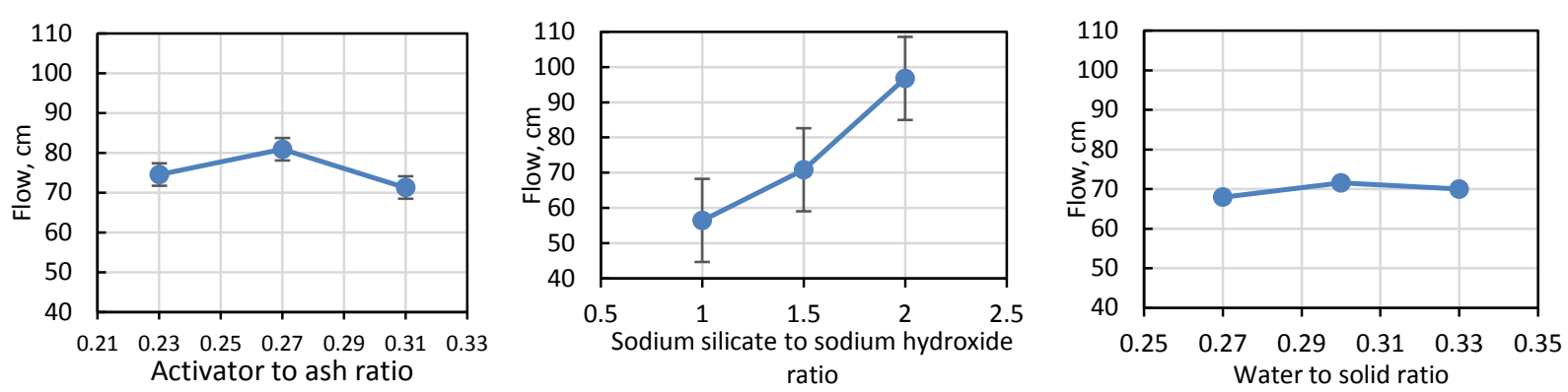

Figure 9. Effects of the optimization mix design variables on the fresh mix flow of geopolymer concrete materials incorporating non-wood biomass ash. 


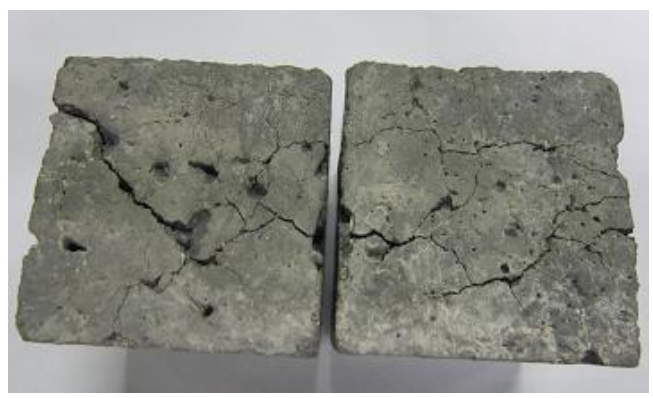

Figure 10. Alkali-activated non-wood biomass ash-based concrete after immersion in boiling water. 


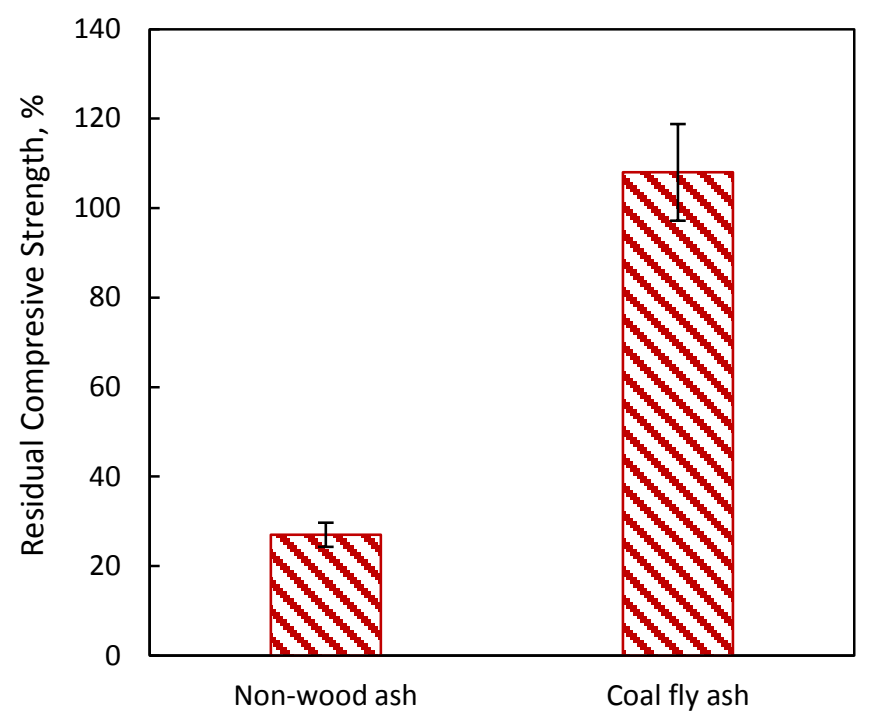

Figure 11. Residual compressive strength, after immersion in boiling water, of alkali-activated concrete materials based on non-wood biomass ash and coal fly ash. 


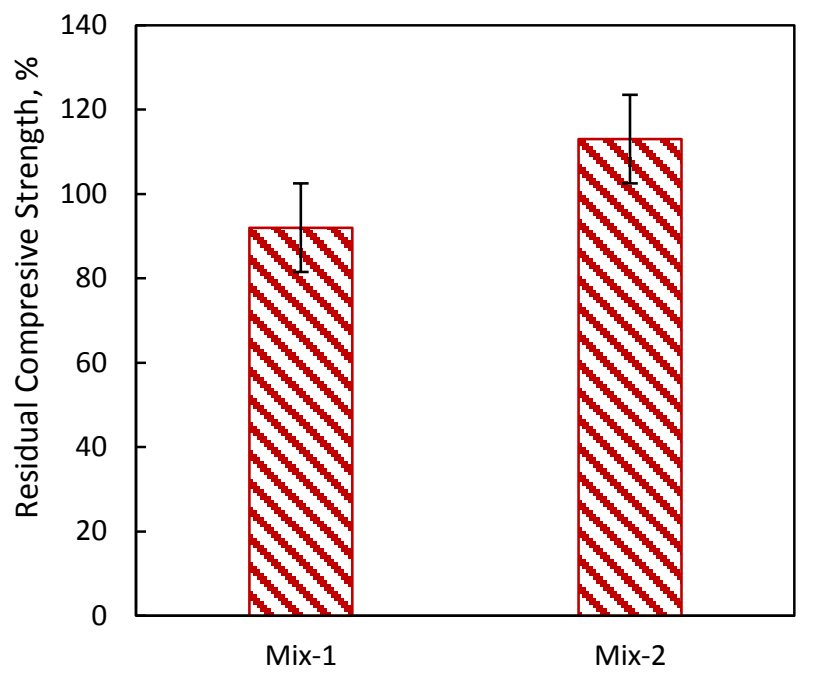

Figure 12. Residual strength (after immersion in boiling water) of alkali-activated concrete materials comprising biomass ash: coal fly ash: metakaolin at 50: 25: 25 weight ratios without (Mix-1) and with (Mix-2) addition of gypsum at 5\% by total weight of ash. 